\title{
EFFECTS OF ETHYLENE GLYCOL SATURATION PROTOCOLS ON XRD PATTERNS: A CRITICAL REVIEW AND DISCUSSION
}

\author{
Regine Mosser-RucK $^{1}{ }^{*}$, Karine Devineau ${ }^{2}$, Delphine Charpentier ${ }^{1}$ and Michel Cathelineau ${ }^{1}$ \\ ${ }^{1}$ UMR CNRS 7566 G2R, UHP, BP 239, 54506 Vandœuvre-lès-Nancy, France \\ ${ }^{2}$ UMR CNRS 7569 LEM, INPL, BP 40, 54501 Vandœuvre-lès-Nancy, France
}

\begin{abstract}
The study of the transformation of smectite to illite, chlorite or vermiculite via interstratified clay minerals needs precise qualitative and quantitative determinations of the different layers in the mixedlayer clays and is generally based on X-ray diffraction (XRD) patterns after specific treatments of the clay samples. Saturation with K or Mg followed by ethylene glycol (EG) solvation are classical methods used to identify high-charge smectite and vermiculite. These procedures have been applied to two experimental clays, one composed of smectite layers and the second, a mixture of vermiculite and smectite layers. Different methods of glycolation (EG vapor or liquid EG) produce significant differences in the XRD patterns. Comparison with literature data indicates that K-saturated, high-charge smectite $(\sim 0.8<$ total charge $<1 /$ unit-cell) and $\mathrm{Mg}$-vermiculite (whatever its charge) do not expand in ethylene glycol vapor $(d$ values $\sim 14-15 \AA$ ). Expansion to $17 \AA$ in liquid ethylene glycol occurs for Mg-vermiculite with a total charge of $<\sim 1.2$ /unit-cell and for $\mathrm{K}$-saturated, high-charge smectite, when the tetrahedral charge is $<\sim 0.7 /$ unit-cell. This study shows that: (1) procedures of glycolation need to be standardized; (2) the use of saturation protocols using both liquid ethylene glycol and ethylene glycol vapor yields useful additional information about the distribution of charges in clay minerals.
\end{abstract}

Key Words-Ethylene Glycol Solvation, High-charge Smectite, K Saturation, Mg Saturation, Vermiculite.

\section{INTRODUCTION}

The transformation of smectites under natural or experimental conditions has been studied intensely in order to describe the processes controlling the nature of clays during diagenesis, weathering or anthropogenic activities such as radioactive waste disposal. In most studies, the characterization of clay layers is carried out by XRD on air-dried and glycol-saturated oriented preparations, sometimes after saturation with different cations $(\mathrm{K}, \mathrm{Mg}, \mathrm{Li}$, etc., see Bouchet et al., 2000 for a compilation). The main objective of glycolation is to identify the nature of the non-swelling clays (illite or chlorite), to discriminate the swelling clays (di- or trioctahedral high-charge or low-charge smectite, vermiculite) and to quantify the nature, degree and ordering of the mixed layering. For a long time, the complexes formed by ethylene glycol or glycerol with clays have received attention because of their use in the identification and characterization of smectites and mixed-layer clays, in particular illite-smectite mixed-layer clays (MacEwan, 1944, 1946; Bradley, 1945; Brindley, 1966). Saturation with glycerol or ethylene glycol produces similar effects but some differences are noticed such as higher $d$ values with glycerol due to the larger size of the molecule, and a variable number of layers of

* E-mail address of corresponding author: regine.ruck@g2r.uhp-nancy.fr

DOI: $10.1346 / C C M N .2005 .0530609$ organic molecules related to the exchangeable cation (reviewed by Bouchet et al., 2000). The expandability of these complexes varies not only with the nature of the mineral, but also with the magnitude and source of the charge in the silicate layers, the number and kind of the exchangeable cations, the particle size and the relative humidity (Walker 1957, 1958; Brindley, 1966; Schultz, 1969; Harward et al., 1969; Środoń, 1980; Sato et al., 1992). In general, it is established that vermiculites form a single-layer complex and smectites a double-layer complex. Beidellite, in comparison with montmorillonite, exhibits differences in expansion upon solvation which are consistent with stronger ionic attraction for tetrahedral than for octahedral charge sites (Harward and Brindley, 1965). The physical state of the solvating agent (liquid, vapor) also yields differences in the rate of expansion (Harward and Brindley, 1965, in Brindley, 1966; Suquet et al., 1975). As a preliminary conclusion, methods of saturation have changed continuously since the middle of $20^{\text {th }}$ century. A careful reading of the literature (summarized below) has shown that several differences and inconsistencies characterize the methods of saturation with polyalcohols (ethylene glycol and glycerol) and that no international standardization of these procedures is available. Therefore, an experimental study was conducted in order to evaluate the relative effects produced by distinct procedures of saturation on the expandability of two clays. The effects of the ethylene glycol saturation method (vapor or liquid) on the swelling was tested for a K-saturated smectite and a Mg-saturated vermiculite. 
Saturation with liquid polyalcohol

Liquid glycerol or liquid ethylene glycol was used in the pioneer works (Bradley 1945; MacEwan, 1948). At that time, air-dried powdered samples were packed in glass capillary tubes, then the sealed ends of the tubes were broken off and held in hot $\left(110^{\circ} \mathrm{C}\right)$ water-free glycerol until glycerol rose by capillarity to the top of the sample (e.g. Barshad, 1950; Reynolds, 1965). In the case of a thin oriented layer of air-dried clay on a glass slide, a few drops of the organic liquid were placed at the edge of the clay sample and allowed to diffuse into it (e.g. Harward et al., 1969; Brindley and Ertem, 1971), or a fine spray (e.g. Inoue et al., 1989) was used so that clay becomes visibly moist. Solvation was also realized by pressing the dry preparation upside down against absorbent paper wetted with ethylene glycol and allowing the composite to remain overnight in this position (e.g. Środon, 1980). Ethylene glycol liquid was sometimes applied directly with a brush (Lanson and Besson, 1992) and excess ethylene glycol was removed just before recording the XRD pattern by pressing the preparation on an absorbent paper. But direct wetting of the slide with the polyalcohols can lead to mechanical disturbances, in particular to the change of particle orientation (Brunton, 1955; Kunze, 1955; Brown and Farrow, 1956).

\section{Saturation with polyalcohol vapor}

Another procedure was then recommended that involved exposing a clay-covered slide to organic vapors in a closed vessel over a heated bath maintained at $60-65^{\circ} \mathrm{C}$ for ethylene glycol (Brunton, 1955; Kunze, $1955)$ and $100^{\circ} \mathrm{C}$ for glycerol (Brown and Farrow, 1956). Brunton (1955) observed that most clay samples glycolated satisfactorily within $1 \mathrm{~h}$ in the vapor at equilibrium with a bath of liquid ethylene glycol at $60^{\circ} \mathrm{C}$, but Brindley (1966) asserted that at least an overnight period in ethylene glycol or glycerol vapors was necessary to establish optimum conditions of solvation. According to Holtzapffel (1985), the saturation in a polyalcohol vapor atmosphere at room temperature should be complete after $12 \mathrm{~h}$.

In the literature, preparation methods of clay samples before an XRD analysis are very different or poorly described. In a few examples, it is stated only that samples are ethylene glycol solvated: "in vapor at $60^{\circ} \mathrm{C}$ " (Inoue et al., 1989); "at $60^{\circ} \mathrm{C}$ for at least $6 \mathrm{~h}$ " (Howard 1981), "at least $12 \mathrm{~h}$ at $\sim 50^{\circ} \mathrm{C} "$ (Bish and Aronson, 1993); only "'overnight" (Huang et al., 1993); "overnight at $60^{\circ} \mathrm{C}$ " (Whitney and Velde, 1993); or "at room temperature for $24 \mathrm{~h}$ ” (Price and McDowell, 1993). No international standard exists concerning the procedure for saturation with polyalcohol vapor.

Effects of $K$ saturation and layer charge of smectite on swelling with polyalcohol

The $\mathrm{K}$ saturation of montmorillonite differs with the site of the charge within a layer structure (Schultz,
1969). A charge in the tetrahedral sheet near the interlayer cation will strongly attract and tends to fix $\mathrm{K}^{+}$ions, making the layer non-expandable, whereas a layer charge mainly in the octahedral sheet far from the exchangeable cation tends to let the layer expand. Other authors (see review in Schultz, 1969) report that expansion after $\mathrm{K}$ saturation is related more to the total amount of net layer charge than to the position of the charge within the layer. According to Schultz (1969), the formation of a double-layer ethylene glycol complex ( $d$ value $=17 \AA$ ) occurs if the negative layer charge of the smectite is 0.85 or less per unit-cell $\left(\mathrm{O}_{20}(\mathrm{OH})_{4}\right)$. According to Sato et al. (1992), K-smectites (montmorillonite and beidellite) with layer charges of 0.68-0.94 (per unit-cell) form $17 \AA$ bi-layer complexes and K-smectites with layer charge of 1.12-1.17 (per unit-cell) form $14 \AA$ monolayer complexes.

In recent works (Bouchet et al., 1988; Righi et al., 1997; Beaufort et al., 2001; Guillaume et al., 2004; Mosser-Ruck and Cathelineau 2004), the identification of high-charge smectite in mixed-layer clays is accomplished using a K-saturated sample heated at $110^{\circ} \mathrm{C}$ overnight and then solvated by ethylene glycol vapor. This procedure is often used and cited in the literature but authors sometimes do not refer to the source, or they refer to sources in which the procedure described is slightly different. Bouchet et al. (1988) refer to Środoń (1980), Howard and Roy (1985) and Środoń et al. (1986). Righi et al. (1997) cite Schultz (1969) and Sato et al. (1992). Certainly, all these works (Schultz 1969; Środoń 1980; Howard and Roy 1985; Środoń et al., 1986; Sato et al., 1992) examine the behavior of expandable smectite layers upon $\mathrm{K}$ saturation to give an estimate of the magnitude of the layer charge but, curiously, none of them deals with heating overnight at $110^{\circ} \mathrm{C}$ on $\mathrm{K}$-saturated samples before saturation with a polyalcohol. The reason why heating overnight at $110^{\circ} \mathrm{C}$ has been introduced to the protocol by some authors (Bouchet et al 1988; Righi et al., 1997) is not explained.

Furthermore, these studies do not use the same solvating agent for the preparation of samples. For example, in Sato et al. (1992), solvations with glycerol and ethylene glycol are accomplished by the vaporpressure methods of Brunton (1955) and Brown and Farrow (1956). In Środoń (1980) and Środoń et al. (1986) liquid ethylene glycol is used by pressing the preparation against absorbent paper overnight and Schultz (1969) uses K-saturated clay slides heated at $300^{\circ} \mathrm{C}$ for $30 \mathrm{~min}$ and treated overnight in ethylene glycol vapor at $60^{\circ} \mathrm{C}$.

\section{Mg-saturation and distinction between smectite and vermiculite}

Harward and Brindley (1965) show that synthetic beidellites and montmorillonite, saturated with $\mathrm{Mg}$, and exposed to glycerol vapor are characterized by a spacing 
of $14.3 \AA$ and $17.8-17.9 \AA$, respectively; exposed to liquid glycerol, a $17.8-17.9 \AA$ spacing is obtained in both cases. The reason why a one-layer glycerol complex is formed in beidellite by glycerol vapor condensation but a two-layer complex in contact with excess liquid is unclear. According to Harward et al. (1969), the Mg-saturated montmorillonites and beidellites generally expand to the equivalent two-layer complex with ethylene glycol vapor $(16.8-16.9 \AA)$. $\mathrm{Mg}$-saturated saponite, in the presence of liquid ethylene glycol or liquid glycerol has a similar behavior to that of the other smectites, i.e. swelling from $16.7 \AA$ in ethylene glycol to $18.1 \AA$ in glycerol (Suquet et al., 1975). For Mg-saturated vermiculites, Harward et al. (1969) concluded that whatever the solvating procedure (ethylene glycol or glycerol, vapor or liquid), $d$ values always range between 14.1 and $14.3 \AA$. These results disagree with those of Walker $(1957,1958)$ who studied the expansion properties upon solvation of five vermiculites characterized by different layer charge, from 1.2 to 1.6 (in equivalents per $\mathrm{O}_{20}(\mathrm{OH})_{4}$ unit of structure). That author noticed that the rate and the degree of expansion of the five $\mathrm{Mg}$-vermiculites saturated with liquid ethylene glycol are related to the layer charge of the vermiculite. The basal $d$ value is $\sim 14.3 \AA$ for $\mathrm{Mg}$ vermiculite with high layer-charge $(>1.4$ in equivalents per $\left.\mathrm{O}_{20}(\mathrm{OH})_{4}\right), 16.3 \AA$ if the layer charge is $<1.2$, and intermediate, $\sim 15.2 \AA$ when the layer charge is between 1.2 and 1.4. Since none of these Mg-saturated vermiculites expands beyond $14.5 \AA$ when solvated with liquid glycerol, Walker $(1957,1958)$ recommends this solvation as a procedure to distinguish between vermiculite and smectite.

\section{MATERIALS, METHODS AND ANALYTICAL TECHNIQUES}

\section{Materials}

The effects of the state of ethylene glycol on the XRD pattern have been tested on two products.

Material ' $A$ ' was obtained experimentally by MosserRuck and Cathelineau (2004). Its mean formula, based on $\mathrm{O}_{20}(\mathrm{OH})_{4}$, is:

$$
\begin{array}{r}
{ }^{\mathrm{IV}}\left(\mathrm{Si}_{7.76} \mathrm{Al}_{0.24}\right)^{\mathrm{VI}}\left(\mathrm{Al}_{3} \mathrm{Fe}_{0.42}^{3+} \mathrm{Mg}_{0.58}\right) \mathrm{O}_{20}(\mathrm{OH})_{4} \\
\mathrm{Ca}_{0.08} \mathrm{Na}_{0.06} \mathrm{~K}_{0.58} x \mathrm{H}_{2} \mathrm{O}
\end{array}
$$

The second material (referred to here as material ' $\mathrm{B}$ ') is a mixture of vermiculite and smectite. It was obtained experimentally by Charpentier et al. (2004). The characterization of vermiculite layers was obtained by analyses of particles (TEM analyses) and Mg saturation of material $\mathrm{B}$ before recording the XRD pattern. The structural formulae of the vermiculite in material B (before $\mathrm{Mg}$ saturation) is:

$$
\begin{array}{r}
{ }^{\mathrm{IV}}\left(\mathrm{Si}_{5.52} \mathrm{Al}_{2.48}\right)^{\mathrm{VI}}\left(\mathrm{Al}_{0.20} \mathrm{Fe}_{4.36}^{2+} \mathrm{Fe}_{1.08}^{3+} \mathrm{Mg}_{0.42}\right) \mathrm{O}_{20}(\mathrm{OH})_{4} \\
\qquad \mathrm{Ca}_{0.32} \mathrm{Na}_{0.40} \mathrm{~K}_{0.04} \times \mathrm{H}_{2} \mathrm{O}
\end{array}
$$

\section{EG saturation protocols}

Material A. A preliminary Ca saturation of material A followed by solvation with ethylene glycol vapor revealed that it was composed of smectite layers. A second saturation with $\mathrm{K}$ was carried out to determine the presence of high-charge smectite layers in material A and to test the effect of both heating to $110^{\circ} \mathrm{C}$ overnight and the state of ethylene glycol (vapor or liquid) following four different saturation protocols: (1) K saturation $+110^{\circ} \mathrm{C}$ (overnight) +24 h-room temperature-EG vapor solvation; (2) K saturation +24 h-room temperature-EG vapor solvation; (3) K saturation +24 h- $65^{\circ} \mathrm{C}-\mathrm{EG}$ vapor solvation; (4) $\mathrm{K}$ saturation + room temperature-EG liquid solvation (a few drops of the organic liquid were placed at the edge of the clay film until the slide was visibly moist).

Material B. The effect of the state of ethylene glycol (vapor and liquid) has been tested following two different saturation protocols: (1) $\mathrm{Mg}$ saturation +24 h-room temperature-EG vapor solvation; (2) Mg saturation + room temperature-liquid EG solvation.

\section{Analytical techniques}

$X R D$. The XRD patterns were recorded using a Bruker ${ }^{\circledR}$ D8 diffractometer, with $\mathrm{CoK} \alpha$ radiation. The patterns were recorded from 3 to $40^{\circ} 2 \theta$, with a step scan of $0.035^{\circ} 2 \theta$ and time per step of $3 \mathrm{~s}$.

The XRD patterns were recorded under similar conditions of relative humidity $(42-46 \%)$ and room temperature $\left(22.6-25.8^{\circ} \mathrm{C}\right)$.

Analyses of material A and material B were carried out by electron microprobe (EMPA) and transmission electron microscopy (TEM) and were reported by Mosser-Ruck and Cathelineau (2004) and by Charpentier et al. (2004).

\section{RESULTS}

The four protocols carried out on K-saturated material A result in rather significant differences in the XRD patterns (Figure 1). If the K-saturated material $\mathrm{A}$ is solvated in $\mathrm{EG}$ vapor at $65^{\circ} \mathrm{C}$ (the widely used method in literature), the $d_{001}$ value is $\sim 15 \AA$. The same result is obtained when it is solvated in EG vapor at room temperature over $24 \mathrm{~h}$. Heating at $110^{\circ} \mathrm{C}$ overnight before EG vapor solvation led to a $d_{001}$ spacing of $\sim 13 \AA$. When material $\mathrm{A}$ is saturated with liquid ethylene glycol, a higher $d$ value is observed $(17 \AA)$. The presence of a weak reflection at $10.09 \AA$ (only on the XRD of the $\mathrm{K}-110^{\circ} \mathrm{C}-\mathrm{EG}$ vapor and $\mathrm{K}-\mathrm{EG}$ vapor samples) is also noticed and could be assigned to nonswelling 'mica-like' crystals (Figure 1).

The XRD patterns presented in Figure 2 show that Mg-vermiculite in material B does not expand after EG vapor saturation (14.26 $\AA$ on $\mathrm{AD}$ and on EG patterns) whereas $\mathrm{Mg}$-smectite expands (14.26 $\AA$ on $\mathrm{AD}$ pattern 


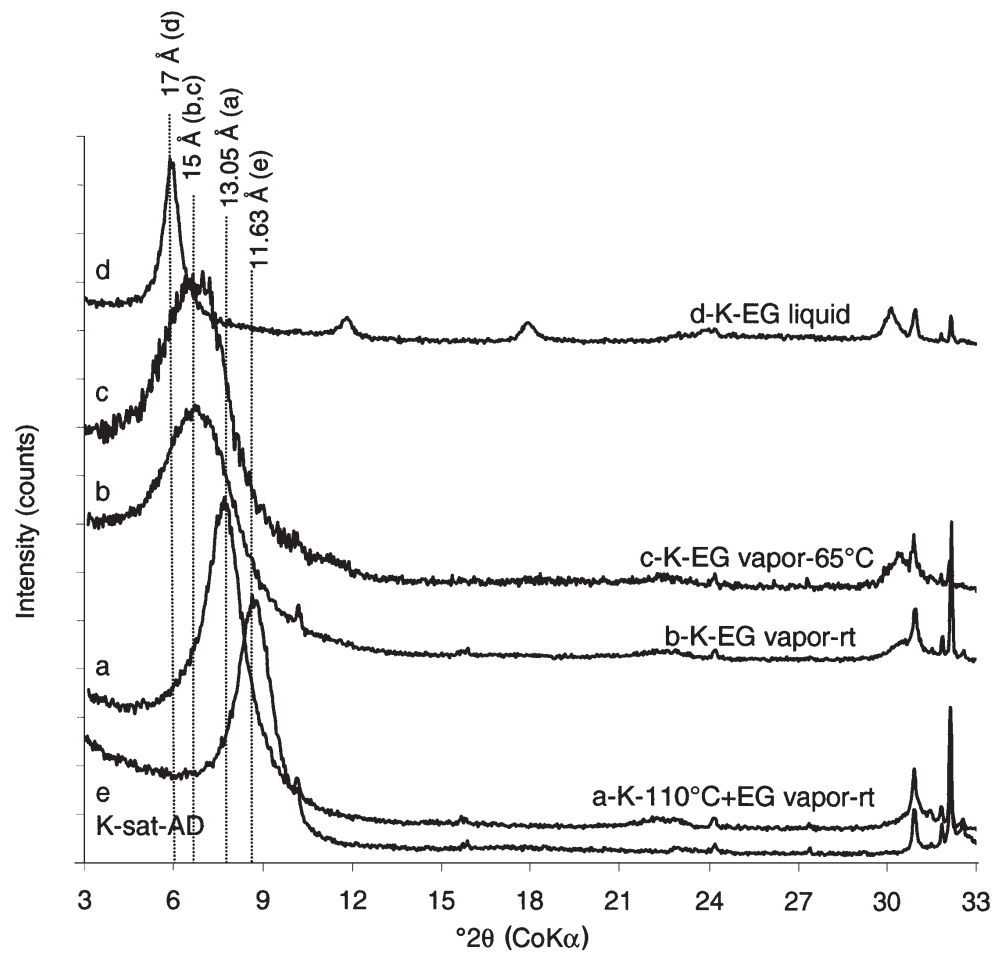

Figure 1. XRD patterns of the K-saturated material noted ' $\mathrm{A}$ ': (a) heating overnight at $110^{\circ} \mathrm{C}$ and solvated with ethylene glycol vapor at room temperature $\left(\mathrm{K}-110^{\circ} \mathrm{C}-\mathrm{EG}\right.$ vapor-rt); (b) solvated with ethylene glycol vapor at room temperature (K-EG vapor-rt); (c) solvated with ethylene glycol vapor at $65^{\circ} \mathrm{C}$ (K-EG vapor $-65^{\circ} \mathrm{C}$ ); (d) solvated with liquid ethylene glycol; (e) air-dried (K-sat-AD). Index of reflections corresponds to $d_{h k l}$ in $\AA$.

and $16.92 \AA$ on EG pattern). The $d$ value at 9.04-9.08 $\AA$ out and shows only one single reflection $(d$ value $=$ is attributed to an associated mineral (mordenite). $16.92 \AA$ ). Mg-vermiculite layers in material B expand in Solvation with liquid ethylene glycol was also carried liquid ethylene glycol but not in ethylene glycol vapor.

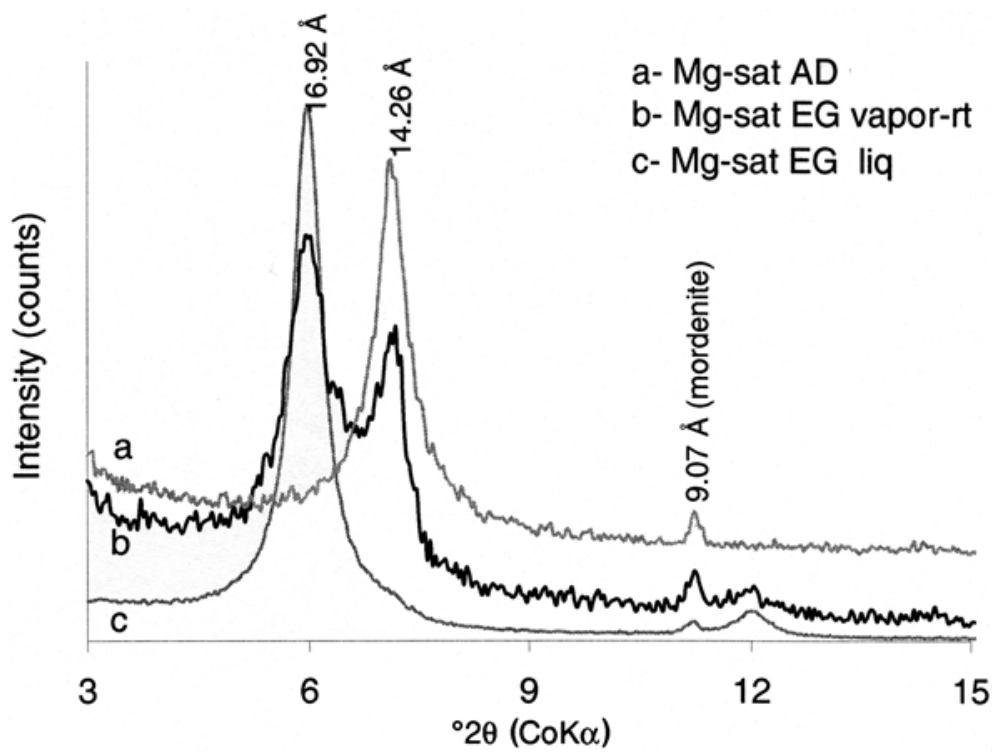

Figure 2. XRD patterns of the air-dried Mg-saturated material B (Mg-sat AD), solvated with ethylene glycol vapor for $24 \mathrm{~h}$ at room temperature (Mg-sat EG vapor-rt) and solvated with ethylene glycol liquid (Mg-sat EG liq). Index of reflections corresponds to $d_{h k l}$ in $\AA$. 


\section{DISCUSSION}

Effects of heating at $110^{\circ} \mathrm{C}$ and the state of ethylene glycol on the XRD pattern of $K$-saturated clay samples

In our test, the variations in $d$ values could be due to several factors: (1) Glass-slide preparations can quickly lose some of the interlayer ethylene glycol as already suggested by Kunze (1955). In our case, XRD patterns were recorded just after the ethylene glycol vapor saturation, so the hypothesis of an EG evaporation can be ruled out. Dyal and Hendricks (1952) demonstrated that evaporation of EG is not significant in K-saturated smectites in the $2 \mathrm{~h}$ following saturation. (2) Walker (1958) specifies that the initial hydration state of interlayer cations has an influence on swelling after glycolation. K-saturated smectites $(\sim 0.8$ charge/unitcell) collapse in a dry atmosphere to $10.3 \AA$ (Sayegh et al., 1965, Bérend et al., 1995). Consequently, glycol retention depends strongly on whether or not the clay has been dried prior to glycol solvation. Air-dried Ksaturated montmorillonite was found to retain $\sim 1.5$ times as much EG as the dried samples (Dyal and Hendricks, 1952). The low glycol retention seen in dried
$\mathrm{K}$-montmorillonite was considered to be related to $\mathrm{K}$ fixation. The role of water in the formation of complexes is predominant and heating perhaps deteriorates the ability to re-expand both in organic liquids and in water itself. Traces of water would be essential to the formation of complexes (Brindley, 1966). These reasons could explain the difference in $d$ values observed when our sample was dried overnight at $110^{\circ} \mathrm{C}$ before the EG saturation. (3) Variations in $d$ values are also related to differences in orientation and packing of the organic molecules (Brindley, 1966). The simple geometry of the ethylene glycol molecule may facilitate different degrees of close-packing as the layer charge of clay minerals increases; single or double-layer complexes of EG can form and are related to the net layer charge of the clay minerals (Brindley, 1966). In our case, the material studied is the same for the four ethylene glycol treatments. Consequently, it is not possible to invoke a variation of the layer charge to explain the different expansions observed on the XRD patterns. In Table 1, literature data show clearly that the swelling of $\mathrm{K}$-saturated smectite with ethylene glycol is dependent on both the total charge and its distribution in the

Table 1. Mean $d_{001}(\AA)$ values of ethylene glycol (EG) solvation complex of K-saturated smectites.

\begin{tabular}{|c|c|c|c|}
\hline Reference & Sample & Solvation method & Basal spacings $(\AA)$ \\
\hline This study & $\begin{array}{l}\text { K-saturated material ' } A \text { ' } \\
\text { Total charge }=0.8 \text { /unit-cell }\end{array}$ & $\begin{array}{c}\text { EG vapor (r.t.) } \\
\text { EG vapor }\left(65^{\circ} \mathrm{C}\right) \\
110^{\circ} \mathrm{C}, 24 \mathrm{~h} \text { before } \\
\text { EG vapor (r.t.) } \\
\text { Liquid EG (r.t.) }\end{array}$ & $\begin{array}{c}15(10.09)^{*} \\
\text { * 'mica-like' crystal } \\
15(10.05)^{*} \\
\text { * ‘mica like' crystal } \\
13.04(10.09)^{*} \\
\text { * 'mica-like' crystal } \\
17\end{array}$ \\
\hline$\dagger$ Brindley, 1966 & $\begin{array}{l}{ }^{\dagger} \text { K-saturated smectites } \\
(\text { total charge }=0.7)\end{array}$ & Liquid EG & 16.9 to 17.1 \\
\hline Schultz, 1969 & $\begin{array}{l}\text { K-saturated smectites } \\
\quad(83 \text { samples })\end{array}$ & $\begin{array}{c}300^{\circ} \mathrm{C}, 1 / 2 \mathrm{~h} \text { before } \\
\mathrm{EG} \text { vapor }\left(60^{\circ} \mathrm{C}\right)\end{array}$ & $\begin{array}{l}17 \text { if total layer charge } \\
\quad<0.85 / \text { unit-cell } \\
13-16 \text { if }>0.85 / \text { unit-cell }\end{array}$ \\
\hline $\begin{array}{l}\text { Weir, } 1960 \text { in } \\
\text { Suquet et al., } 1975\end{array}$ & $\begin{array}{l}\text { K-saturated beidellite } \\
\text { (Black Jack Mine-Idaho, } \\
\text { total layer charge }=0.96 / \text { unit- } \\
\text { cell, tetrahedral charge }=0.96 \text { ) }\end{array}$ & Liquid EG & 14.7 \\
\hline Suquet et al., 1975 & $\begin{array}{c}\text { K-saturated saponite (total } \\
\text { charge }=0.92 / \text { unit-cell) }\end{array}$ & Liquid EG & 16.5 \\
\hline $\begin{array}{l}\text { Glaeser - personal } \\
\text { communication in } \\
\text { Suquet et al., } 1975\end{array}$ & $\begin{array}{l}\text { K-saturated beidellite }{ }^{\$} \text { Rupsroth- } \\
\text { Germany, total charge }=1.17 \\
\text { tetrahedral charge }=0.75 \text { ) }\end{array}$ & Liquid EG & 14 \\
\hline Sato et al., 1992 & $\begin{array}{l}\text { K-saturated smectites } \\
\quad(10 \text { samples })\end{array}$ & EG vapor $\left(65^{\circ} \mathrm{C}\right)$ & $\begin{array}{l}16.9-17.34 \text { if total layer is } \\
\sim 0.68-0.94 / \text { unit-cell and } \\
\text { tetrahedral charge }<0.5 / \text { unit-cell } \\
14 \text { if total charge is } \\
1.12-1.17 / \text { unit-cell and } \\
\text { tetrahedral charge }>0.7 / \text { unit-cell }\end{array}$ \\
\hline
\end{tabular}

r.t.: solvated at room temperature; ${ }^{\dagger}$ : data compiled from different authors. ${ }^{\#}$ Layer charge mentioned by Schultz (1969). ${ }^{\$}$ Layer charge mentioned by Sato et al. (1992). 
different crystallographic sites. Moreover, the behavior of a further sample of the same K-saturated smectite would be different depending on the state of the ethylene glycol used to solvate it. K-saturated smectites characterized by a total layer charge $>\sim 1$ (per unit-cell) do not expand in ethylene glycol vapor at $60-65^{\circ} \mathrm{C}$ (Sato et al., 1992) or in liquid ethylene glycol (Weir, 1960; Glaeser, pers. comm., in Suquet et al., 1975). If the total charge is between 0.85 and $1, \mathrm{~K}$-saturated smectites generally do not expand in ethylene glycol vapor (Schultz, 1969) except if tetrahedral charge is very low $<0.5$ (Sato et al., 1992), and they expand to $16.9-17 \AA$ in liquid ethylene glycol (Suquet et al., 1975). This contrasting behavior could be related to the amount of the tetrahedral charge of the K-saturated smectite. Expansion in liquid ethylene glycol could be possible for K-saturated high-charge smectite $(\sim 0.8<$ total charge $<1$ /unit-cell) only if tetrahedral charge is $<0.7$, referring to the results of Glaeser (in Suquet et al., 1975). This would require that certain layers admit liquid EG but not EG vapor. Comparison of our results with the data in Table 1 suggests that material A could be a mixedlayered clay composed of both low-charge and highcharge smectite layers $(\sim 0.8<$ total charge $<\sim 1$ / unitcell) because of a basal spacing of $15 \AA$ when the sample is saturated in EG vapor. But the expandability (17 $\AA$ ) observed when it is saturated with liquid EG can be due to the presence of high-charge smectite with tetrahedral charge $<0.7 /$ unit-cell.

Effect of the state of ethylene glycol on the XRD pattern of Mg-saturated clay sample

Our results show that the contrasting behavior of $\mathrm{Mg}$ vermiculite in material $\mathrm{B}$ is dependent on its layer charge, confirming the literature data (Table 2). Displacement of the basal reflection towards higher spacings $(16.3-17 \AA$ ) when $\mathrm{Mg}$-vermiculite is solvated in liquid ethylene glycol, is noticed only for low-charge vermiculite $\left(<1.2\right.$ per $\left.\mathrm{O}_{20}(\mathrm{OH})_{4}\right)$, such as that from Young River in Australia (Walker, 1957, 1958). This is also typically the case for the vermiculite in material B. By contrast, after solvation in ethylene glycol vapor, the basal reflection always occurs at $\sim 14.2 \AA$ whatever the layer charge of vermiculite.

\section{CONCLUSIONS}

This study has shown that differences and inconsistencies exist in literature concerning the methods of saturation with polyalcohols (ethylene glycol and glycerol). No international standards for these procedures are available at the present time.

Based on XRD results obtained after different saturation protocols of a K-saturated smectite and a Mg-vermiculite, our study shows that: (1) treatment with EG vapor at $\sim 60^{\circ} \mathrm{C}$ or at room temperature leads to the same saturation ratios if duration of solvation at room temperature is at least $24 \mathrm{~h}$; (2) heating to $110^{\circ} \mathrm{C}$ overnight could induce either a partial or a complete lack of re-expansion of K-saturated smectite layers in ethylene glycol vapor; (3) liquid ethylene glycol leads to the expansion to $17 \AA$ of $\mathrm{K}$-saturated, high-charge smectite layers when they have a low tetrahedral charge $(<\sim 0.7 /$ unit-cell), and of low-charge Mg-saturated vermiculite $(<1.2 /$ unit-cell).

The various behaviors of K-saturated, high-charge smectite and Mg-saturated vermiculite facing the different treatments confirm the strong dependency of expandability to the saturation procedure with polyalcohol and the difficulty of correlating expandability with the mineralogy and the type of layering in mixedlayered clays. The present study is restricted to two

Table 2. Mean values of $d_{001}(\AA)$ of ethylene glycol (EG) solvation complex of Mg-saturated vermiculites.

\begin{tabular}{|c|c|c|c|}
\hline Reference & Sample & Solvation method & Basal spacings $(\AA)$ \\
\hline This study & $\begin{array}{l}\text { Mg-saturated material ' } \mathrm{B} \text { ' } \\
\text { vermiculite } \\
\text { Total layer charge }=1.16\end{array}$ & $\begin{array}{l}\text { EG vapor (r.t.) } \\
\text { Liquid EG (r.t.) }\end{array}$ & $\begin{array}{l}14.26 \\
16.92\end{array}$ \\
\hline Walker (1958) & Mg-vermiculite & Liquid EG & $\begin{array}{c}14.3 \text { if layer charge is } \\
>1.4 \text { per } \mathrm{O}_{20}(\mathrm{OH})_{4} \\
16.3 \text { if layer charge is } 1.2 \text { or less } \\
15.2 \text { for intermediate } \\
\text { layer charge }(1.3)\end{array}$ \\
\hline $\begin{array}{l}\dagger \text { Brindley (1966) } \\
\text { * vermiculite from } \\
\text { Young River } \\
\text { (Australia) }\end{array}$ & $\dagger$ Mg-vermiculite & Liquid EG & $\begin{array}{c}14.3 ; 16.3 * \\
(* \text { total layer charge }=1.2)\end{array}$ \\
\hline $\begin{array}{l}\text { Harward et al. } \\
\text { (1969) }\end{array}$ & $\begin{array}{l}\text { Mg-vermiculites } \\
\quad(12 \text { samples }) \\
\text { layer charge }>1.3\end{array}$ & $\begin{array}{l}\text { EG vapor }\left(60-65^{\circ} \mathrm{C}\right) \\
\text { Liquid } \mathrm{EG}\end{array}$ & $\begin{array}{l}14.22 \\
14.25\end{array}$ \\
\hline
\end{tabular}

r.t.: solvated at room temperature; $\uparrow$ : data compiled from different authors. 
samples obtained from experiments. To confirm the conclusions, well-known reference clays should be necessary to characterize fully the inferred processes using various polyalcohol saturation protocols.

\section{ACKNOWLEDGMENTS}

We are very grateful to Dr J. Cuadros (National History Museum, London) and Dr R. Ferrell (Associate Editor) for reviewing the manuscript and for their constructive suggestions.

\section{REFERENCES}

Barshad, I. (1950) The effect of interlayer cations on the expansion of the mica type crystal lattice. American Mineralogist, 35, 225-238.

Beaufort, D., Berger, G., Lacharpagne, J.C. and Meunier, A. (2001) An experimental alteration of montmorillonite to a di+trioctahedral smectite assemblage at 100 and $200^{\circ} \mathrm{C}$. Clay Minerals, 36, 211-225.

Bérend, I., Cases, J.M., Francois, M., Uriot, J.P., Michot, L., Masion, A. and Thomas, F. (1995) Mechanisms of adsorption and desorption of water vapor by homoionic montmorillonites: 2. The $\mathrm{Li}+, \mathrm{Na}+, \mathrm{Rb}+$, and $\mathrm{Cs}^{+}$-exchanged forms. Clays and Clay Minerals, 43, 324-336.

Bish, D.L. and Aronson, J.L. (1993) Paleogeothermal and paleohydrologic conditions in silicic tuff from Yucca Montain, Nevada. Clays and Clay Minerals, 41, 148-161.

Bouchet, A., Proust, D., Meunier, A. and Beaufort, D. (1988) High-charge to low-charge smectite reaction in hydrothermal alteration processes. Clay Minerals, 23, 133-146.

Bouchet, A., Meunier, A. and Sardini, P. (2000) Minéraux argileux: structure cristalline, identification par diffraction des rayons X. Bulletin du Centre de Recherche Elf Exploration et Production, 23, 136 pp.

Bradley, W.F. (1945) Molecular association between montmorillonite and some polyfunctional organic liquids Journal of the American Chemical Society, 67, 975-981.

Brindley, G.W. (1966) Ethylene glycol and glycerol complexes of smectite and vermiculites. Clay Minerals, 6, 237-259.

Brindley, G.W. and Ertem, G. (1971) Preparation and solvation properties of some variable charge montmorillonites. Clays and Clay Minerals, 19, 399-404.

Brown, G. and Farrow, R. (1956) Introduction of glycerol into flakes aggregates by vapour pressure. Clay Minerals Bulletin, 3, 44-45.

Brunton, G. (1955) Vapour glycolation. American Mineralogist, 40, 124-126.

Charpentier, D., Devineau, K., Mosser-Ruck, R., Cathelineau, M. and Villiéras, F. (2004) Bentonite-iron interactions under alkaline condition: an experimental approach (submitted to Applied Clay Science).

Dyal, R.S. and Hendricks, S.B. (1952) Formation of mixed layer minerals by potassium fixation in montmorillonite. Proceedings of the Soil Science Society of America, 16, 45-48.

Guillaume, D., Neaman, A., Cathelineau, M., Mosser-Ruck, R., Peiffert, C., Abdelmoula, M., Dubessy, J., Villiéras, F. and Michau, N. (2004) Experimental study of the transformation of smectite at 80 and $300^{\circ} \mathrm{C}$ in the presence of $\mathrm{Fe}$ oxides. Clay Minerals, 39, 17-34.

Harward, M.E. and Brindley, G.W. (1965) Swelling properties of synthetic smectite in relation to lattice substitutions. Clays and Clay Minerals, 13, 209-222.

Harward, M.E., Carstea, D.D. and Sayegh, A.H. (1969) Properties of vermiculite and smectites: Expansion and collapse. Clays and Clay Minerals, 16, 437-447.
Holtzapffel, T. (1985) Les minéraux argileux. Préparation. Analyse diffractométrique et détermination. Société Géologique du Nord, 12, 136 pp.

Howard, J.J. (1981) Lithium and potassium saturation of illite/ smectite clays from interlaminated shales and sandstones. Clays and Clay Minerals, 29, 136-142.

Howard, J.J. and Roy, D.M. (1985) Development of layer charge and kinetics of experimental smectite alteration. Clays and Clay Minerals, 33, 81-88.

Huang, W.L., Longo, J.M. and Pevear, D.R. (1993) An experimental derived kinetic model for smectite-to-illite conversion and its use as a geothermometer. Clays and Clay Minerals, 41, 162-177.

Inoue, A., Bouchet, A., Velde, B. and Meunier, A. (1989) Convenient technique for estimating smectite layer percentage in randomly interstratified illite/smectite minerals. Clays and Clay Minerals, 37, 227-234.

Kunze, G.W. (1955) Anomalies in the ethylene glycol solvation technique used in X-ray diffraction. Clays and Clay Minerals, 3, 83-93.

Lanson, B. and Besson, G. (1992) Characterization of the end of smectite-to-illite transformation: Decomposition of X-ray patterns. Clays and Clay Minerals, 40, 40-52.

MacEwan, D.M.C. (1944) Identification of the montmorillonite group of minerals by X-rays. Nature, 154, 577-578.

MacEwan, D.M.C. (1946) The identification and estimation of the montmorillonite group of minerals, with special reference to soil clays. Journal of the Society of Chemical Industry, 65, 298-304.

MacEwan, D.M.C. (1948) Complexes of clays with organic compounds. I. Complex formation between montmorillonite and halloysite and certain organic liquids. Transactions of the Faraday Society, 44, 349-367.

Mosser-Ruck, R. and Cathelineau, M. (2004) Experimental transformation of $\mathrm{Na}, \mathrm{Ca}$-smectite under basic conditions at $150^{\circ} \mathrm{C}$. Applied Clay Science, 26, 259-273.

Price, K.L. and McDowell, S.D. (1993) Illite/smectite geothermometry of the Proterozoic Oronto group, midcontinent rift system. Clays and Clay Minerals, 41, $134-147$.

Reynolds, R.C. (1965) An X-ray study of an ethylene glycolmontmorillonite complex. American Mineralogist, 50, 990-1001.

Righi, D., Räisänen, M.L. and Gillot, F. (1997) Clay mineral transformation in podzolized tills in central Finland. Clay Minerals, 32, 531-544.

Sato, T., Watanabe, T. and Otsuka, R. (1992) Effects of layer charge, charge location, and energy change on expansion properties of dioctahedral smectites. Clays and Clay Minerals, 40, 103-113.

Sayegh, A.H., Harward, M.E. and Knox, E.G. (1965) Humidity and temperature interaction with respect to K-saturated expanding clay minerals. American Mineralogist, 50, $490-495$.

Schultz, L.G. (1969) Lithium and potassium absorption, dehydroxylation temperature, and structural water content of aluminous smectites. Clays and Clay Minerals, 17, $115-149$.

Środoń, J. (1980) Precise identification of illite/smectite interstratification by X-ray powder diffraction. Clay and Clay Minerals, 28, 401-411.

Środoń, J., Morgan, D.J., Eslinger, E.V., Eberl, D.D. and Karlinger, M.R. (1986) Chemistry of illite/smectite and endmember illite. Clays and Clay Minerals, 34, 368-378.

Suquet, H., De la Calle, C. and Pezerat, H. (1975) Swelling and structural organization of saponite. Clays and Clay Minerals, 23, 1-9.

Walker, G.F. (1957) On the differentiation of vermiculite and smectites in clays. Clay Minerals Bulletin, 3, 154-163. 
Walker, G.F. (1958) Reactions of expanding lattice clay
minerals with glycerol and ethylene glycol. Clay Minerals minerals with glycero
Bulletin, 3, 302-313.

Weir, A.H. (1960) Relationship between physical properties, structure and composition of smectite. Thesis, London University.
Whitney, G. and Velde, B. (1993) Changes in particle morphology during illitization: An experimental study. Clays and Clay Minerals, 41, 209-218.

(Received 5 November 2004; revised 15 June 2005; Ms. 979; A.E. Ray E. Ferrell, Jr.) 